\title{
An Empirical Analysis of Macroeconomic and Bank-Specific Factors Affecting Bank Deposits in Vietnam
}

\author{
Vu Thi Phuong Thao ${ }^{1} \&$ Le Trung Thanh ${ }^{2}$ \\ ${ }^{1}$ Thuyloi University, Hanoi, Vietnam \\ ${ }^{2}$ University of Economics and Business, Vietnam National University, Hanoi, Vietnam \\ Correspondence: Vu Thi Phuong Thao, Thuyloi University, Hanoi, Vietnam. Tel: 84-984-962-887.
}

Received: October 9, 2020

Accepted: November 22, 2020

Online Published: January 14, 2021

doi:10.5430/ijfr.v12n2p172

URL: https://doi.org/10.5430/ijfr.v12n2p172

\begin{abstract}
This paper investigates the macroeconomic and bank-specific factors that determine bank deposits in Vietnam. To explore the association, A Fixed and random effect model was performed on a data set of 40 banks from 2006 to 2019. Studied bank-specific factors include capital adequacy ratio, profitability, bad loan, liquidity and listing. In addition, GDP and inflation are the macroeconomic factors considered. Based on panel data analysis, it is suggested that bank-specific factors such as bank size, bad loan, profitability GDP and inflation have a notable effect on bank depositsAmong these factors, profitability and GDP showed a positive effect on bank depositsIn contrast, Bank size, bad loan and inflation showed an insignificant effect on bank deposits. The study also highlights some new factors to provide a better understanding of bank deposits in emerging economies like Vietnam.
\end{abstract}

Keywords: deposit, macroeconomic, bank-specific, commercial banks, Vietnam

\section{Introduction}

One of the key determinants of a country's economic growth and development is the strength and sustainability of the financial system made up of a bank-based system in which investment capital is provided and monitored by the banks (Adem, 2015). Banks serve as intermediaries in mobilizing savers' funds and then lending them to individual/corporate investors. Deposits are undoubtedly the core of commercial banks' operations. By definition, bank deposits consist of money placed into commercial banks by customers to earn some interest and also for safekeeping. Literature has shown that bank deposit plays a key role in accelerating economic growth, particularly in developing and emerging economies (Ogege \& Shiro, 2013; Ünvan, 2020). Vietnam as a developing country with a relatively underdeveloped capital market is not an exception.

\section{Literature Review}

\subsection{Theoretical Underpinnings}

Commercial banks depend on depositors' deposits. According to Keynes's theory of money needs, there are three main motivations for people to hold money: trading, hedge, and investing. To cater to these incentives, commercial banks offer different types of deposits: deposits and savings. Deposits are designed for people who need money for trading purposes. This incentive is viewed from the perspective of consumers who want income to meet their household spending and from the perspective of businesses that need the money and want to keep it to continue in business. Therefore, the purpose of the deposit is for the convenience of making daily payments. If the deposit is to perform daily transactions, the type of savings deposit serves the needs of those who want to save and increase income. Depositors in savings accounts also have an incentive to prevent unforeseen circumstances (Haron \& $\mathrm{Al}$, 2003).

Developing Keynes's theory, there are three main theories related to thrifty behavior: Permanent Income hypothesis (Friedman, 1957), Life cycle model - Modigliani \& Brumberg (1954) and the more recent theory of specific saving behavior by Deaton (1989) and (Carroll, 1992) is the buffer-stock theory.

The absolute income hypothesis was introduced by Keynes in 1936. The hypothesis that consumption is dependent only on personal income, so saving is a part of income over expenditure. Extending Keynes's point of view, Friedman (1957) argues that the best way to understand savings and consumption behavior is to consider how 
individuals properly plan to spend their wealth in life. The permanent income hypothesis predicts that a higher future income will reduce present savings. Conducting a simultaneous and independent study, Modigliani \& Brumberg (1954) proposed a life cycle hypothesis that emphasizes that the main driver of savings is accumulation for retirement. According to him, in the early stages of an active life, an individual will spend more than what they earn, by borrowing, knowing that their future income will increase. Their savings rate is then negative. This percentage of savings turns positive and will increase until the individual reaches maximum income, in the years before retirement. After they retire, they'll pay off those savings. So, the savings rate, in one's life cycle, has the shape of a bell. And so that savings, like consumption, are not determined by current income. Modiglian $(1966,1970)$ argues that a high growth rate increases the total income of workers compared with retirees and dependents, thereby increasing the combined savings rate. This argument is also strongly supported by Attanasio et al. (2000).

Some new developments in the permanent income hypothesis are Carroll's (1992) buffer stock savings behavior theory. This theory argues that individuals holding assets with an incentive to protect their consumption against unpredictable fluctuations in income. The theory assumes that consumers become impatient and cautious when they are faced with important sources of income but are uncertain. They are impatient because they have to borrow against future income to meet current consumption levels, and they are also cautious because they need to be on the lookout. To avoid the risks of future earnings fluctuations as well as ensure consumption, consumers are forced to make provisions by minimizing their current consumption to save for incidental incidents. Thus, makes the savings rate cyclical, which means that individuals tend to save more when their incomes are higher to meet consumption in bad times.

As such, there are three main motivations for people to hold money: trading, prevention, and investment. To cater to these incentives, commercial banks offer different types of deposits and savings. Deposits can be viewed from the point of view of consumers wanting income to meet their household spending and from the perspective of entrepreneurs who need the money and want to keep it to do their business.

\subsection{Empirical Review of Related Literature}

An important criterion to evaluate the success and efficiency of any financial institution, especially commercial banks, is the level of deposit mobilization of the people. However, this is not a simple problem as it depends on a lot of factors. N. Desinga (1975) has classified factors that are believed to affect commercial bank deposits including macroeconomic and bank-specific factors.

The country's economic, social, and political factors can affect commercial bank deposits. According to Harald \& Heiko (2008), country-specific risks such as political, economic, and financial risks can affect the tendency of depositors to put money into the banking system. In general, a bank's success in its operations largely depends on the environment in which it operates. Researchers have identified some country-specific factors that affect deposits at commercial banks including interest rates, inflation, economic growth, shocks.

\subsubsection{Interest Rate}

Masson et al. (1998) argued that interest rates are positively related to deposit growth at banks in developing countries in Africa and Latin America, but the results are not very strong. This result is similar to the research result of Haron and Azmi (2008) at banks in Malaysia.

Meanwhile, when studying the determinants of deposits at Muslim banks in Indonesia, Erna \& Ekki (2004) found that convenient depositors at Islamic banks were mainly motivated by profit motives. They choose banks with higher interest rates to deposit money. This is in the same way as Lomuto (2008), Finger \& Hesse (2009) when studying deposits at banks in Kenya. Attractive interest rates also account for about $78 \%$ of the variation in deposits at Ghanaian banks, proving that interest rates are attractive to those with spare money to save (Eric et al., 2015). When studying G7 countries in the period 1960-1999, Cohn and Kolluri (2003) also found a positive response of saving behavior to interest rate.

Tuyishine, Florence and Zenon (2015) indicated that interest rates affect the level of deposits and later on the profitability of the bank. Contrary on the study on determinants of deposit mobilization and related costs of Commercial Banks in Ethiopia, carried out by Girgan Garo (2015), reveales that interest rates and the volume of deposit correlated negatively with each other. The same findings can be witnessed in the studies of Siyambola (2012) and Wubitu (2012). Their regression analysis shows that there is an opposite relationship between the interest and the deposit growth. 


\subsubsection{Inflation}

Inflation was seen as an economic problem in developed countries in the second half of the 20th century. Inflation affects economic growth, employment, income distribution and wealth as well as the main conditions. the social rule of a country (Mohammad \& Mahdi, 2010). The banking system as an important efficiency factor in economic activity is also affected by inflation. This is when inflation increases, the real interest rates on money and assets decrease; hence deposits are no longer attractive.

The banking system is affected by inflation in terms of deposit absorption (Mohammad \& Mahdi, 2010). According to Mohammad \& Mahdi (2010), in developed countries a negative correlation between inflation and deposits has been observed. However, in developing countries the opposite is true. Similarly, in Nigeria, Ojeaga \& Odejimi (2013) shows that interest rates have a significant positive effect on bank deposits. Meanwhile, Haron \& Azmi (2006) reported that the inflation rate has a negative effect on bank deposits in Malaysia.

\subsubsection{Economic Growth}

Economic growth is measured by GDP (Gross Domestic Product), a variable that has also become the common measure of living standards. It is universally adopted by common standards and has a number of undeniable benefits mainly due to its simplicity. As gross domestic product increases, in addition to the transactional demand for money, there is an increase in community savings (Sandhu and Goswami, 1986). While demographic variables have important effects on savings rates in Asia, per capita income in Africa and income growth in Latin America are considered important. The determinants of saving behavior in developing countries are studied by Masson et al. (1998) and they found that GDP growth is positively related to savings in the above group of countries, although there is a slight difference in the degree of these relations.

According to Herald \& Heiko (2008), growth is one of the decisive factors for commercial bank deposits. GDP is calculated by adding the value-added at each stage of production (subtracting the cost of raw materials purchased and the material purchased from the industry suppliers. Erna \& Ekki (2004) found four variables: GDP, the number of Islamic bank branches, the rate of return, and interest rates are said to have an effect on the volume of deposits. So, GDP may affect the growth of commercial bank deposits.

In addition to the macroscopic factors explored in the previous section, factors that belong to commercial bank characteristics can play an important role in explaining deposit needs at the bank level (Haral \& Heiko, 2009). In this section, the author gives an overview of some of the factors that belong to commercial banks that affect their deposits.

\subsubsection{Liquidity}

The higher liquidity buffer (as measured by the ratio of liquid assets to deposits) tends to favor demand for deposits. Harald \& Heiko (2008) argued that the bank liquidity situation also plays an important role in determining bank deposit growth. Higher liquidity banks are associated with higher deposit growth. According to Nada (2010), banks are considered risky if they have more difficulty attracting deposits and lending than banks that are considered safe. When the banks fail to pay the depositors, they face liquidity risks that prevent other depositors from depositing the money into that bank.

\subsubsection{Profitability}

The profitability of a bank is often measured by the ratio of profit after tax (net profit) to average total assets or by the ratio of profit after tax to average equity. Erna \& Ekki (2004) found that the relationship between commercial bank deposits and profitability of banks is a long-term relationship. Higher bank profits tend to signal bank stability, which can make it easier for these banks to attract more deposits (Harald \& Heiko, 2008). However, the effect of bank returns and bank size is found to be insignificant under control for other variables. Therefore, the effect of profitability and bank size on commercial bank deposits is lower than for other variables.

\subsubsection{Bank Size}

One of the prominent factors identified as influencing deposit volatility is bank size. In most documents, a bank's total assets are used as a representation of a bank's size. Previous studies have had mixed conclusions about the impact of bank size on bank deposits. Molyneux and Thornton (1992), Bikker and Hu (2002), Goddard et al. (2007), and Ikuko \& Konishi (2007) find a positive relationship between deposit size and growth. The large scale as well as a larger branch network helps banks mobilize more deposits than small banks. Contrary to the above point of view, Kaufman (1972) and Herald \& Heiko (2008) argued that the smaller banks, while generating fewer deposits in 
absolute terms, had relative growth in deposits. It is higher than the larger banks, so it may be beneficial for small banks to achieve higher deposit growth.

\subsubsection{Bad Loan}

Research on deposits in the US, Park and Peristiani (1998) demonstrated a negative relationship between deposit growth and bad debt ratio in banks. The high NPL ratio makes depositors feel insecure when depositing into those banks, which reduces the amount of money deposited at the bank. Ikuko \& Konishi (2007) believe that the bad loan ratio is one of the factors that negatively affect deposit growth. For banks that do not meet the requirements for financial health and safety, deposits will decrease.

\section{Situation of Growth From Customer Deposits at Vietnamese Commercial Banks}

\subsection{Deposit Scale Growth}

The financial statement analysis of selected commercial banks show that the size of total customer deposits has increased by 2.58 times over a six-year period, from 3,067 trillion VND on December 31, 2013 to 7,917 trillion VND on June 30,2019. The average growth rate of customer deposits was $18.2 \%$ in the period $2013-2017$. The highest deposit growth rate was observed in 2013 with $22.2 \%$ then saw a steady decrease in recent years, however still keeping at two digits growth rate until it reached the bottom at 11.8\% in 2018 (Figure 1).

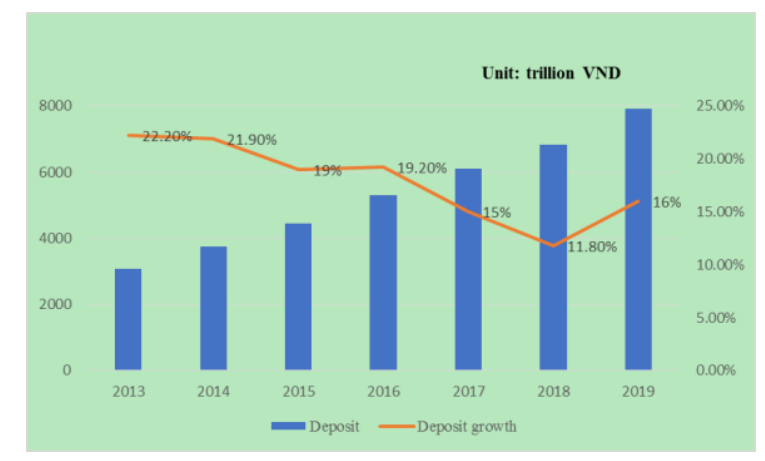

Figure 1. Deposit growth at Vietnamese commercial banks in the period of 2013 - 2019

Source: Financial statements of commercial banks

\subsection{Classification of Customer Deposits by Term}

In fact, to diversify the portfolio of deposit products provided to customers as well as creating the initiative and flexibility for customers when making deposits, the term of deposits is very diverse, including Short term (1 month, 2 months, 3 months, 6 months, 9 months, 12 months), medium and long term ( 24 months, 36 months, 60 months ...). Therefore, it is possible to classify customer deposit terms as follows: Short-term (less than 12-month term), medium-term (the term from 1 to 5 years), and long-term (term of more than 5 years).

From 2013 to 2019, there is a noticeable shift in customer deposit structure of Vietnamese commercial banks towards increasing the proportion of long-term deposits and gradually reducing the proportion of short-term deposits: The proportion of short-term capital mobilization of commercial banks in 2013 was $94.6 \%$, in 2017, this proportion dropped sharply by $13.5 \%$ to $81.1 \%$, then increased by $9.1 \%$ to $90.2 \%$ in 2019 .

Capital mobilization for long terms increased mainly in terms of 1 to 5 years. The proportion of medium-term capital mobilization in 2003 was $4.7 \%$, in 2017, it increased by $11.1 \%$ to $15.8 \%$, then decreased to $7.5 \%$ by the end of 2019 .

The proportion of deposits for long terms over 5 years increased by $1.4 \%$ from $0.7 \%$ to $2.3 \%$ in 2019. Details of customer deposit rates by the term of the selected commercial banks for the period 2013 - 2019 are shown in Figure 2. 


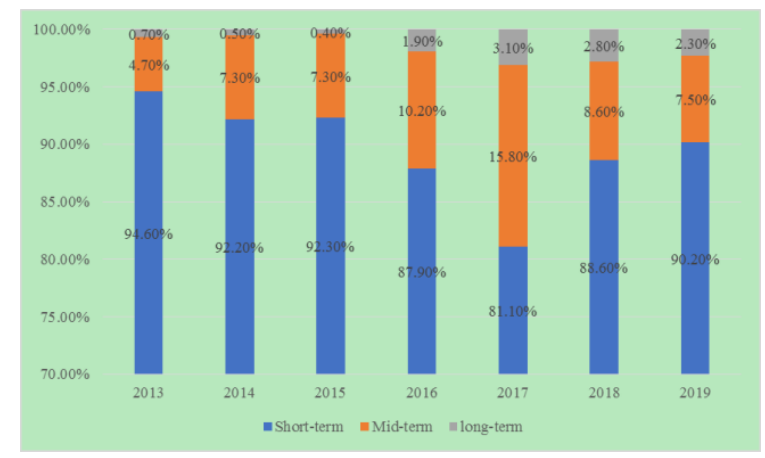

Figure 2. Deposits from customers at commercial banks by period of 2013 - 2019

\subsection{The Ability of Banks to Meet Credit Needs}

The Calculation and analysis show that, basically, the capital raised from customers' deposits ensures a balanced use of capital of commercial banks. Specifically, the ratio of customer loans to customers (before provision) on average customer deposits of commercial banks was $91.3 \%$, or in other words, the ratio of customer deposits to customer loans of commercial banks on average is $110 \%$. This result demonstrates the importance of deposits from customers in business activities of the bank in general and credit operations of the bank in particular.

\subsection{Current Situation of Customer Deposits by Banking Group}

In order to increase the effectiveness in comparing and evaluating, banks are divided into four groups according to the charter capital size as of December 31,2019. Specific groups are as follows:

- Group 1: Charter capital of over VND 20,000 billion (4 commercial banks)

- Group 2: Charter capital from VND 5,000 billion to VND 20,000 billion (17 commercial banks)

- Group 3: Charter capital from VND 3,500 billion to less than VND 5,000 billion (2 commercial banks)

- Group 4: Charter capital of less than VND 3,500 billion (8 commercial banks).

The results show that, from 2013 to 2019, commercial banks of group 1 (including large commercial banks such as Vietcombank, BIDV, Agribank, Vietinbank) tend to have the most stable growth compared to the remaining groups (standard deviation 3.74\%), while deposit growth from customers of commercial banks in group 2 and group 3 tends to be the most unstable (standard deviations are $7.78 \%$ and $8.97 \%$ respectively) (Table 1).

Table 1. Developments of customer deposit growth in commercial banks

\begin{tabular}{llllllllll}
\hline Group banks & $\mathbf{2 0 1 3}$ & $\mathbf{2 0 1 4}$ & $\mathbf{2 0 1 5}$ & $\mathbf{2 0 1 6}$ & $\mathbf{2 0 1 7}$ & $\mathbf{2 0 1 8}$ & $\mathbf{2 0 1 9}$ & Average & Standard deviation \\
\hline $\mathbf{1}$ & 17,4 & 22,2 & 19,8 & 23,2 & 17,4 & 11,9 & 11,5 & 17,6 & 3,74 \\
\hline $\mathbf{2}$ & 34 & 24,5 & 17,7 & 17,1 & 12,4 & 11,3 & 10,7 & 18,2 & 7,78 \\
\hline $\mathbf{3}$ & 35,6 & 17,1 & 18,8 & 28,9 & 15,4 & 13,9 & 14,1 & 20,5 & 8,97 \\
\hline $\mathbf{4}$ & 26,3 & 26,9 & 28,2 & 21,6 & 11,6 & 15,1 & 12,6 & 20,3 & 6,26 \\
\hline
\end{tabular}

Compared to the average customer deposit growth rate of the commercial banks in group 1 (17.6\%), while the banks in group 2 are similar (18.2\%), the banks in group 3 and group 4 grew higher at $20.5 \%$ and $20.3 \%$ respectively.

Data calculated from financial statements of commercial banks show some remarkable results when analyzing the characteristics of customer deposit terms classifying by banks (Figure 3).

There is a similar change in direction of shifting in the capital mobilization structure of the banking groups in the period 2015-2019 as to the general trend of the banking system. The proportion of medium, long-term capital mobilization is increasing while the propotion of short-term deposit is decreasing. Group 1 and Group 2 have the most obvious changes, with the proportion of short-term deposits to total deposits of customers in 2019 decreased by $2.4 \%$ and $5.8 \%$ compared to 2015 . 

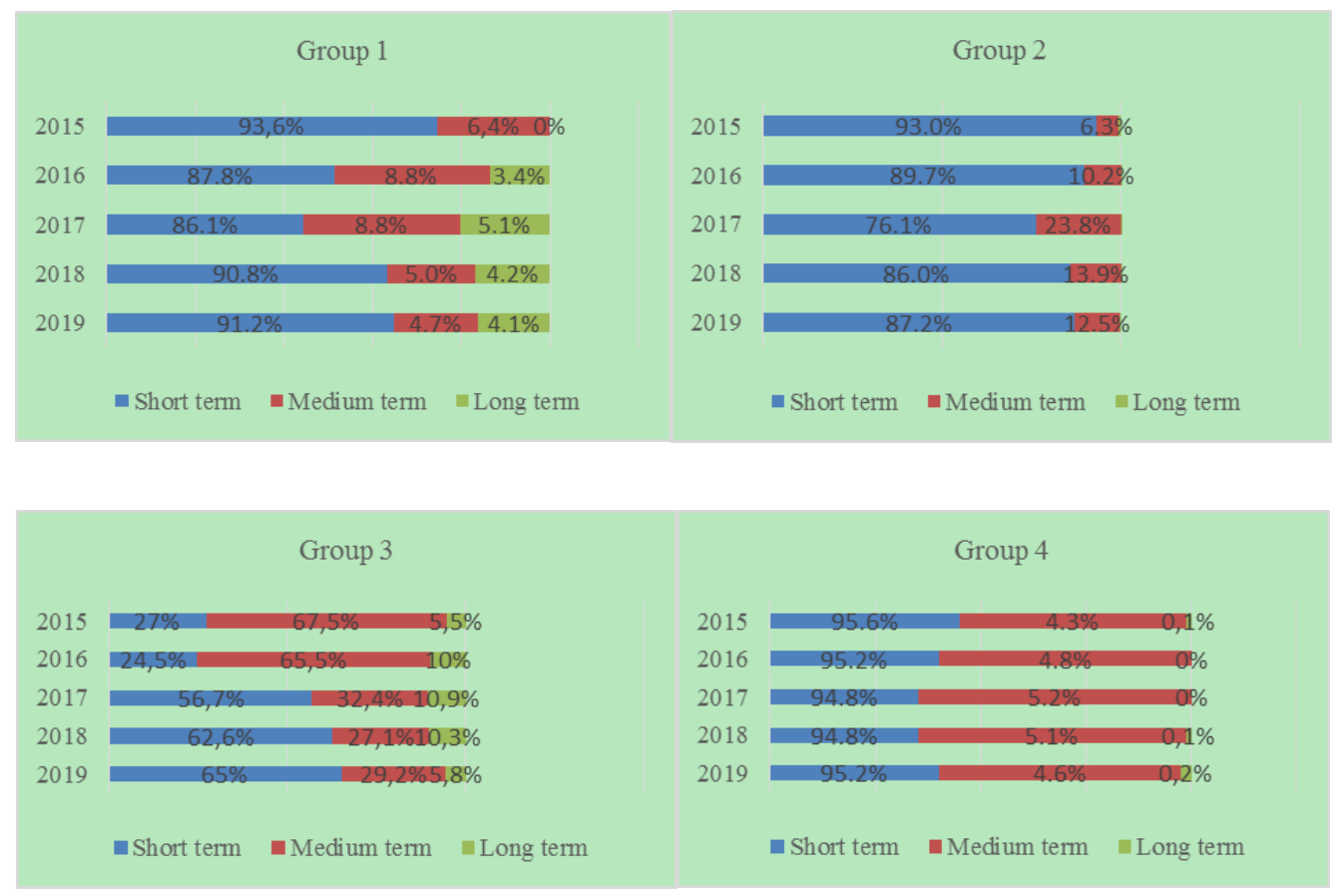

Figure 3. Term of deposit of groups commercial bank groups

Secondly, deposit growth from customers with long terms in the period of 2015 - 2019 (over 5 years) increased sharply in banks of group 1 (up 4.1\%) and group 3 (up $2.3 \%$ ).

While the banks of group 1 are big, reputable commercial banks and brands in the market with total deposits from customers, accounting for 58\% of total deposits of commercial banks, including Vietcombank, BIDV, Agribank, Vietinbank, the banks in group 3 are commercial banks with the highest long-term capital mobilization interest rates on the market today. The analysis of this data shows that the prestige, bank brand as well as deposit interest rates of commercial banks have a certain impact on the size of customer deposits.

\section{Data and Methodology}

\subsection{Sample and Data}

The research time series is from 2006 to 2019. Financial figures are figures at the end of each quarter. Macro factors data is collected from the website of the International Monetary Fund (IMF). Data on elements belonging to commercial banks is collected from the financial statements of 40 commercial banks (as of December 31, 2019) and the State Securities Commission.

\subsection{Methodology}

Based on the theory of savings and deposits, based on research models of some domestic and foreign authors and the current situation of deposits at Vietnamese commercial banks, the author builds a research model on the relationship. The relationship between fluctuations of deposits and the factors affecting deposits is as follows:

$$
\begin{gathered}
\text { DEPOSITi }, \mathrm{t}=\alpha 1 \mathrm{CAPITALi}, \mathrm{t}+\alpha 2 \mathrm{ASSETi}, \mathrm{t}+\alpha 3 \mathrm{BADLOANi}, \mathrm{t}+\alpha 4 \mathrm{ROAi}, \mathrm{t}+\alpha 5 \mathrm{LIQUIDi}, \mathrm{t}+\alpha 6 \mathrm{LISTi}, \mathrm{t}+\alpha 7 \mathrm{GDPi}, \mathrm{t} \\
+\alpha 8 \mathrm{CPIi}, \mathrm{t}+\varepsilon \mathrm{i}, \mathrm{t}
\end{gathered}
$$

Deposit volatility (DEPOSIT) is understood as the growth rate of deposits by quarter.

Capital Adequacy ratio (CAPITAL): The equity capital of a financial institution has the ability to "absorb" various types of potential risks (such as credit risks and market risks) to ensure the stability of that credit institution and protection of creditors (Dietrich \& Wanzenried, 2011). The CAR is a reflection of the bank's ability to offset losses in terms of assets, the higher the ratio, the safer the bank (Hasbi \& Haruman, 2010). However, the CAR is often calculated by banks for governance needs as well as at the request of regulators and is rarely disclosed in their 
financial statements. Therefore, another index used by the author to represent the capital adequacy of the CAR replacement bank is the ratio of equity to total assets.

Bad loan (BADLOAN) is represented by the ratio of bad debts / total outstanding loans. In general, a bank's risk mainly comes from the loan portfolio, so it is required to assess the health and quality of a bank's assets through monitoring the financial health of the borrower as well as measuring the ratio of NPLs to total outstanding loans as a proxy for credit quality is essential (Baral, 2005). The higher the NPL ratio, the lower the credit quality.

Profitability (ROA) is expressed in the ROA ratio. The profitability of banks can be measured by different ratios, the most common being the ratio of profit after tax to average assets (ROA) (Ayadi \& Pujals (2005), Athanasoglou, 2006). This ratio indicates how efficient a bank is in using assets to generate profits (Sangmi \& Nazir, 2010). Neal (2004) argues that the ROA reflects a bank's ability to use assets to generate income and therefore any change in the ROA overtime is necessary to evidence to evaluate the effectiveness of a bank.

Liquidity (LIQUID): Liquidity is represented by the ratio of cash and highly liquid assets to total assets. Bank liquidity measures the solvency of its current obligations (Hazzi \& Kilani, 2013). Bank liquidity is calculated by the ratio of liquid assets to total assets of the bank (Laurent (1979), Canbas et al. (2005), Vodová (2013), and Chagwiza (2014)).

Bank size (ASSET) is represented by the bank's total assets. Bank size is usually measured by the natural logarithm of a bank's entire assets. Various studies show that the effect of real vessel size on bank deposits is not really clear. In general, larger banks can take advantage of economies of scale, thereby increasing their deposits (Molyneux and Thornton (1992), Bikker and Hu (2002), and Goddard et al. (2007)). However, Kaufman (1972) and (Herald \& Heiko, 2008) argued that smaller banks, while generating fewer deposits in absolute terms, had relatively higher deposit growth rates than other Large banks, therefore, can be beneficial to small banks in achieving higher deposit growth. The author uses the logarithm for the purpose of bringing the absolute number of assets into a smaller number, consistent with the value of the factors in the regression model (in the form of a ratio).

Inflation (CPI): The inflation rate is measured by the annual growth rate of the consumer price index (CPI). Inflation was proved by Herald \& Heiko (2008) as one of the decisive factors for bank deposits. Research by Mohammad \& Mahdi (2010) and Ünvan \& Yakubu (2020) also support this result by assuming that inflation has a significant impact on savings and term deposits.

Economic growth (GDP): There are many studies assuming that the growth of economic activity, as measured by growth in the gross domestic product (GDP), has a positive effect on deposits at banks because it is an increase in income increases, leading to an increase in savings and investment. Economic growth is expected to contribute to bank deposit growth. Previous studies by Masson et al. (1998), (Erna \& Ekki, 2004), and Herald \& Heiko (2008) report the positive effect of GDP growth on bank deposit growth.

\section{Result Analyses}

Following is a statistical table describing the variables in the model (Table 2)

Table 2. Descriptive statistics of the variables in the model

\begin{tabular}{lllllll}
\hline VarName & Obs & Mean & Median & SD & Min & Max \\
\hline DEPOSIT & 1843 & 8.799 & 5.370 & 14.489 & -12.971 & 48.923 \\
\hline CAPITAL & 1868 & 11.700 & 9.147 & 7.226 & 4.934 & 33.021 \\
\hline ASSET & 1868 & 17.672 & 17.666 & 1.403 & 14.908 & 20.082 \\
\hline BADLOAN & 2200 & 4.152 & 2.974 & 4.358 & 0.000 & 15.330 \\
\hline ROA & 2200 & 1.045 & 0.443 & 1.443 & 0.000 & 5.160 \\
\hline LIQUID & 1868 & 4.028 & 3.070 & 2.867 & 1.022 & 11.603 \\
\hline CPI & 2200 & 1.762 & 1.151 & 1.865 & -0.190 & 7.465 \\
\hline LIST & 2200 & 0.200 & 0.000 & 0.400 & 0.000 & 1.000 \\
\hline GDP & 2200 & 7.758 & 12.883 & 24.915 & -36.613 & 42.226 \\
\hline
\end{tabular}


Study a total of 40 banks for the period 2006-2019, quarterly data. However, in the period 2006 to 2019, there are many banks that do not have sufficient data established by banks after 2006, by merging with other banks or acquired by the State Bank.

The average value of the deposit growth variable is 8.8 , with the largest value being 48.92 and the lowest value being -12.97. The variable equity over total assets fluctuates from a value of 4.93 to 33.02 and has an average value of 11.7.

The logarithmic variable of an asset varies from 14.91 to 20.08 and has an average value of 17.67. The variable of bad debt ratio has an average value of 4.15 , the maximum value is 15.33 and the lowest value is 0 . Variable cash and assets with high liquid value over total assets ranging from 1.02 to 11.6 and mean at 4.03 . The return on total assets variable varies from 0 to 5.16 and has an average value of 1.05 . The consumer price index variable fluctuates from -0.19 to 7.47 and has an average value of 1.76 . The variable gross domestic product fluctuates from -36.61 to 42.22 and has an average value of 7.76 .

With bank databases collected between 2006 and 2019, the Pearson Correlation test shows a correlation between research variables.

Table 3. Correlation matrix between variables

\begin{tabular}{lllllllll}
\hline & DEPOSIT & CAPITAL & ASSET & BADLOAN & ROA & LIQUID & CPI & GDP \\
\hline DEPOSIT & 1 & & & & & & \\
\hline CAPITAL & $0.176^{* * *}$ & 1 & & & & & \\
\hline ASSET & $-0.237^{* * *}$ & $-0.698^{* * * *}$ & 1 & & & & & \\
\hline BADLOAN & $-0.054^{* *}$ & 0.009 & $0.078^{* * *}$ & 1 & & & \\
\hline ROA & $-0.140^{* * *}$ & $-0.114^{* * *}$ & $0.352^{* * *}$ & $-0.145^{* * *}$ & 1 & & \\
\hline LIQUID & 0.026 & 0.023 & 0.005 & 0.008 & $-0.059^{* *}$ & 1 & \\
\hline CPI & $0.198^{* * *}$ & $0.161^{* * *}$ & $-0.196^{* * *}$ & 0.010 & $-0.227^{* * *}$ & $0.123^{* * *}$ & 1 & \\
\hline GDP & $-0.068^{* * *}$ & -0.027 & -0.017 & -0.022 & $0.128^{* * *}$ & $0.044^{*}$ & $-0.042^{*}$ & 1 \\
\hline
\end{tabular}

Through analysis, we see that the relationship between the variable ASSET and CAPITAL is highly correlated. The other variables have a low correlation.

Table 4 shows the results of the research model on the relationship between forwarding movement with variables on CAPITAL, ASSET, LIQUID, BADLOAN, ROA, LIST, CPI and GDP in the period 2006 - 2019. The author conducted a relationship survey in the whole period from 2006 - 2019 and divided it into 3 phases: 2006 - 2010, 2011 - 2015, 2016 - 2019. The values have a statistical significance of $10 \%$ or more. will be marked with *, values with statistical significance of $5 \%$ or more will be marked **, values with statistical significance of $1 \%$ or more will be marked with $* * *$. The results show that the impact level of factors such as macro and banks themselves on deposit fluctuations is different in each period.

Table 4. FEM model regression results through stages

\begin{tabular}{lllll}
\hline & & $2006-2010$ & $2011-2015$ & $2016-2019$ \\
\hline VARIABLES & DEPOSIT & DEPOSIT & DEPOSIT & DEPOSIT \\
\hline CAPITAL & 0.123 & 0.118 & $0.725^{*}$ & 0.0528 \\
\hline ASSET & $(0.135)$ & $(0.180)$ & $(0.270)$ & $(0.498)$ \\
\hline BADLOAN & $-2.559^{* * *}$ & -0.706 & $-6.478^{* * *}$ & $-0.683^{* * *}$ \\
\hline & $(0.866)$ & $(1.052)$ & $(2.418)$ & $(2.746)$ \\
\hline
\end{tabular}




\begin{tabular}{lllll}
\hline & & $2006-2010$ & $2011-2015$ & $2016-2019$ \\
\hline ROA & $0.160^{* *}$ & $1.114^{*}$ & 0.0664 & $0.198^{* *}$ \\
\hline LIQUID & $(0.265)$ & $(0.957)$ & $(0.403)$ & $(0.258)$ \\
\hline & 0.231 & $1.088^{* * *}$ & 0.0837 & 0.167 \\
\hline CPI & $(0.197)$ & $(0.308)$ & $(0.268)$ & $(0.164)$ \\
\hline LIST & $-1.000^{* * *}$ & 0.391 & $-1.650^{* * *}$ & $-0.851^{* *}$ \\
\hline & $(0.221)$ & $(0.373)$ & $(0.278)$ & $(0.710)$ \\
\hline GDP & $0.0886^{*}$ & $-0.899^{* *}$ & 1.819 & 0.0511 \\
\hline & $(1.296)$ & $(4.021)$ & $(1.352)$ & $(1.400)$ \\
\hline Constant & $0.0380^{* *}$ & $0.0345^{* *}$ & $0.0493^{* *}$ & 0.000181 \\
\hline & $(0.0167)$ & $(0.0350)$ & $(0.0231)$ & $(0.0160)$ \\
\hline Observations & $51.49^{* * *}$ & 19.64 & $-120.1^{* *}$ & 17.21 \\
\hline Number of KG & $(16.26)$ & $(19.00)$ & $(44.95)$ & $(52.91)$ \\
\hline R-squared & 1,837 & 711 & 702 & 424 \\
\hline
\end{tabular}

\subsection{The Period 2006-2010}

The p-value of (F-statistic) of the model is $0<5 \%$, so the model is statistically significant. The R-squared value of the model is 0.483 . This means that the variables in this model account for $48.3 \%$ of the variation in deposit growth rate. This is a pretty high percentage in social studies. With the significant level of 5\%, the 1-period lag variables of LIQUID, LIST, and GDP have an impact on the deposit growth rate. The variable LIQUID has a positive impact on deposit growth. For banks with high liquidity in the previous quarter, deposit growth was faster. The variable LIST has a positive effect on deposit growth. With banks listed on the stock market, deposit growth is faster. The variable GDP has a positive impact with the growth of deposits. When domestic product growth in the previous quarter was high, deposit growth was faster.

\subsection{The Period 2011-2015}

The p-value of (F-statistic) of the model is $0<5 \%$, so the model is statistically significant. The R-squared value of the model is 0.391 . That means the variables in this model are explained $39.1 \%$ variation of deposit growth rate. This is a pretty high percentage in social studies. With a significance level of 5\%, the 1-period lag variables of ASSET, BAD LOAN, CPI, and GDP have an impact on the deposit growth rate. The ASSET variable has the opposite effect on deposit growth. For large banks in the previous quarter, deposit growth was slower. The variable BAD LOAN has the opposite effect on deposit growth. For banks with large NPLs in the previous quarter, deposit growth was slower. The variable CPI harms deposit growth. When inflation in the previous quarter was high, deposit growth was lower. The variable GDP has a positive impact on the growth of deposits. When domestic product growth in the previous quarter was high, deposit growth was faster.

\subsection{The Period 2016-2019}

The Prob (F-statistic) value of the model is $0<5 \%$, so the model is statistically significant. The R-squared value of the model is 0.282 . This means that the variables in this model account for $28.2 \%$ of the variation in deposit growth rate. This is a pretty high percentage in social studies. With a significance level of 5\%, the 1-period lag variables of ASSET, ROA, and CPI have an impact on deposit growth. The ASSET variable has the opposite effect on deposit growth. For large banks in the previous quarter, deposit growth was slower. ROA variable has a positive impact on deposit growth. For banks with high ROA in the previous quarter, deposit growth is faster. The variable CPI harms deposit growth. When inflation in the previous quarter was high, deposit growth was lower. 


\subsection{The Period 2006 - 2019}

The R-squared value of the model is 0.351 . This means that the variables in this model account for $35.1 \%$ of the variation in deposit growth rate. This is a pretty high percentage in social studies. With a significance level of 5\%, the 1-period lag variables of ASSET, BAD LOAN, ROA, CPI, and GDP have an impact on the deposit growth rate. The ASSET variable has the opposite effect on deposit growth. For large banks in the previous quarter, deposit growth was slower. The variable BAD LOAN has the opposite effect on deposit growth. For banks with large NPLs in the previous quarter, deposit growth was slower. ROA variable has a positive impact on deposit growth. For banks with high ROA in the previous quarter, deposit growth is faster. The variable CPI harms deposit growth. When inflation in the previous quarter was high, deposit growth was lower. The variable GDP has a positive impact on the growth of deposits. When domestic product growth in the previous quarter was high, deposit growth was faster.

\section{Conclusions}

This study examined the effect of macroeconomic and bank-specific factors on Bank Deposits in Vietnam. The results indicated that GDP, inflation, bank size, bad loan, and profitability significantly affect bank deposits. These include profitability and GDP showed a positive effect on bank deposits. Bank size, bad loans, and inflation showed an insignificant effect on bank deposits.

Firstly, in the period 2006-2010, the growth rate of deposits in Vietnamese commercial banks depends on two groups of factors: macro factors and village factors. bank body. With a statistical significance of 5\%, the research results show that liquidity, listing status, and economic growth have an impact on the growth rate of bank deposits.

This period witnessed the world financial crisis in 2007. However, Vietnam has not been deeply integrated into the world economy, so it has not been affected much. During this period, the Vietnamese banking system grew strongly in the size of assets and capital. Credit growth and average capital growth in the period 2006-2010 were both high. The banking system always achieves high profits. Besides, a series of banks began to list shares on stock exchanges and began to publicly disclose their periodic reports at the request of the State Securities Commission. By 2008, the liquidity situation started to be tense, the deposit interest rate sometimes reached 19\%/year. However, the Government and State Bank of Vietnam assessed that the financial crisis did not have a major impact on Vietnamese banks. Therefore, the deposit growth rate is still at a stable growth rate.

Deposit growth is not affected by the risk factors of the economy and the banking system has a positive effect in that the source of deposits in banks is relatively stable. But this also means that depositors are less concerned with banking risks, market discipline has not been enforced, and in the long term, affects the financial strength and internal resilience of the banking system. State support is also limited, especially in the context of the budget deficit ceiling rising to $5.3 \%$ and Vietnam's public debt ratio being quite high (over $60 \%$ of GDP).

Secondly, in the period 2011-2015, the results show that with a significant level of 5\%, asset size, overdue debt ratio, inflation and speed Gross domestic product growth has an impact on deposit growth. Thus, in this period, deposit growth is not affected by the ratio of equity to total assets, liquidity and profitability ratio of the bank.

The results in this stage can be explained by a number of reasons as follows:

Since 2011, the Vietnamese economy has begun to decline in economic growth due to the impact of the global financial crisis from outside and its internal weakness. Prices of some investment items fell sharply, especially real estate prices. The banking system before 2010 had weaknesses (such as low credit quality, poor governance), but it was not revealed because banks can still expand lending, maintain revenue from credit in the market. The school also has good expectations for the increase in real estate prices and large projects. After 2010, many risks were revealed as losses. After many years the banking system has grown in size and profitability, depositors have become accustomed to good information about the economy and the banking system, and bad news about banks in the market. Deposit money is more concerned, received more cautiously, with more careful consideration. Therefore, they will pay attention and consider the risk factors of the bank when deciding to deposit money. Besides, it is possible that due to the reduction of the saving rate in the population stemming from inflation, the decrease in gross domestic product growth, and the decrease in income, deposits in banks also increase at a slow rate.

The period 2011-2015 is the time to implement the project of economic restructuring, with special emphasis on restructuring the banking system through consolidation, the merger of weak banks, and establishment of Vietnam Asset Management Company (VAMC) to handle bad debts of banks. From 2012 to 2014, the bad debt of the bank was revealed more clearly. In 2015, there was a series of mergers and acquisitions of joint-stock commercial banks, also, the State Bank acquired 3 commercial banks due to ineffective operation leading to weakness. Interest rates fell quickly to support businesses to borrow capital, restore production and business, but the ability of the economy to 
absorb the view, credit growth is slow. Depositors are concerned about the size of their assets and become cautious with news about bank bad debts. Banks with a high ratio of NPLs to total outstanding loans find it more difficult to raise capital from people's deposits.

Third, the period 2016-2019 is the second phase of the process of restructuring the banking system. At the 5\% significance level, asset size, rate of return, and inflation have an impact on deposit growth.

This is phase 2 of the Project of Restructuring the financial - banking system. Depositors find that the bank mergers have caused some disruption, but their interests have not been affected. At the same time, depositors may be accustomed to the weak point of bank mergers that their deposits are still preserved. In fact, mergers are just grouping banks together and deposits are just moving from one bank to another. Therefore, they do not pay much attention to the risk factors of the bank when depositing.

The liquidity of the commercial banking system was ensured, stable, and cross-ownership was reduced in the commercial banking system, preventing bank failures and bankruptcy. The confidence of people in the banking system and the VND was strengthened and guaranteed, there was no massive withdrawal at weak banks. Lending interest rates tend to decrease gradually and stabilize until now, contributing to supporting businesses to save costs when borrowing from banks to expand production and business. After mergers, depositors are more interested in the profitability of banks, reflected in the growth of deposits depending on the profitability of banks.

The State Bank supports liquidity for the banking system but does not put pressure on inflation, liquidity, and inflation and the consumer price index are stable with lower risks.

One of the requirements for the banking industry in the 2016-2020 restructuring period is to require all commercial banks to be listed on the stock exchange to ensure transparency. However, by the first half of 2020, there were only 17/31 banks listed on the stock exchange. The deposit growth rate in this period was not affected by the listed status of banks, which can be partly explained by the fact that commercial banks are now proactively disclosing their financial statements as well as information that has a great influence. to an investor's decision on their bank's website.

\section{References}

Adem, S. B. (2015). Determinants of commercial bank deposits in Ethiopia: A case of commercial bank of Ethiopia. Degree of Master Thesis, Addis Ababa University.

Athanasoglou, P., Delis, M., \& Staikouras, C. (2006). Determinants of bank profitability in the South Eastern European region.

Attanasio, O. P., Picci, L., \& Scorcu, A. E. (2000). Saving, growth, and investment: a macroeconomic analysis using a panel of countries. Review of Economics and Statistics, 82(2), 182-211.

Ayadi, R., \& Pujals, G. (2005). Banking mergers and acquisitions in the EU: Overview, assessment and prospects (No. 2005/3). SUERF Studies.

Bikker, J. A., \& Hu, H. (2002). Cyclical patterns in profits, provisioning and lending of banks and procyclicality of the new Basel capital requirements. PSL Quarterly Review, 55(221).

Boadi, E. K., Li, Y., \& Lartey, V. C. (2015). Determinants of bank deposits in Ghana: Does interest rate liberalization matters?. Modern Economy, 2015(6), 990-1000.

Canbas, S., Cabuk, A., \& Kilic, S. B. (2005). Prediction of commercial bank failure via multivariate statistical analysis of financial structures: The Turkish case. European Journal of Operational Research, 166(2), 528-546.

Carroll, C. D., Hall, R. E., \& Zeldes, S. P. (1992). The buffer-stock theory of saving: Some macroeconomic evidence. Brookings Papers on Economic Activity, 1992(2), 61-156.

Chagwiza, W. (2014). Zimbabwean commercial banks liquidity and its determinants. International Journal of Empirical Finance, 2(2), 52-64.

Cohn, R. A., \& Kolluri, B. R. (2003). Determinants of household saving in the G-7 countries: recent evidence. Applied Economics, 35(10), 1199-1208.

Deaton, A. (1989). Saving and liquidity constraints (No. w3196). National Bureau of Economic Research.

Desinga, R. N. (1975). Deposit Mobilization by Co-operative Banks. A Comparison Economic and Political Weekly, 29, 1098-1100.

Dietrich, A., \& Wanzenried, G. (2011). Determinants of bank profitability before and during the crisis: Evidence from Switzerland. Journal of International Financial Markets, Institutions and Money, 21(3), 307-327. 
Erna, R., \& Ekki, S. (2004). Factors Affecting Mudaraba Deposits in Indonesia. Working Paper in Economics and Development Studies, Padjadjaran University, Indonesia.

Finger, M. H., \& Hesse, H. (2009). Lebanon-determinants of commercial bank deposits in a regional financial center (No. 9-195). International Monetary Fund.

Friedman, M. (1957). The permanent income hypothesis. In A theory of the consumption function (pp. 20-37). Princeton University Press.

Fueda, I., \& Konishi, M. (2007). Depositors' response to deposit insurance reforms: Evidence from Japan, 1990-2005. J Finan Serv Res, 31(2007), 101-122.

Garo, G. (2015). Determinants of deposit mobilization and related costs of commercial banks in Ethiopia. A Research Project Paper Submitted to the Department of Management College of Business and Economics.

Goddard, J., Molyneux, P., Wilson, J. O., \&Tavakoli, M. (2007). European banking: An overview. Journal of Banking \& Finance, 31(7), 1911-1935.

Harald, F., \& Heiko, H. (2008). Lebanon-Determinants of commercial banks Deposits in a Regional Financial Center. IMF Working paper, WP/09/195.

Haron, S., Azmi, W. N. W., \& Shafie, S. (2006). Deposit determinants of commercial banks in Malaysia. Finance India, 20(2), 531.

Kaufman, G. G. (1972). Deposit variability and bank size. The Journal of Financial and Pp Quantitative Analysis, 7(5), 2087-2096.

Laurent, C. R. (1979). Improving the efficiency and effectiveness of financial ratio analysis. Journal of Business Finance \& Accounting, 6(3), 401-413.

Lomuto, J. K. (2008). Determinants of Kenyan commercial banks deposit growth. Masters Thesis, University of-Nairobi, Nairobi.

Masson, P. R., Bayoumi, T., \& Samiei, H. (1998). International evidence on the determinants of private saving. The World Bank Economic Review, 12(3), 483-501.

Modigliani, F., \& Brumberg, R. (1954). Utility analysis and the consumption function: An interpretation of cross-section data. Franco Modigliani, 1(1), 388-436.

Mohammad, N., \& Mahdi, S. (2010). The Role of Inflation in Financial Repression: Evidence. Iran World Applied Sciences Journal, 11, 653-661.

Molyneux, P., \& Thornton, J. (1992). Determinants of European bank profitability: A note. Journal of Banking \& Finance, 16(6), 1173-1178.

Nada, M. (2010). Can Banks Provide Liquidity in a Financial Crisis?. Federal Reserve Bank of Kansas City, Economic Revision.

Ojeaga, P., Ojeaga, D., \& Odejimi, D. O. (2013). The Impact of Interest Rate on Bank Deposits Evidence from the Nigerian Banking Sector.

Sandhu, H. S., \& Goswami, R. K. (1986). Determinants of commercial bank deposits in India. Indian Economic Journal, 34(1), 41.

Sangkyun, P., \& Peristiani, S. (1998). Market discipline by thrift depositors. Journal of Money, Credit and Banking, 30, 347-364.

Sangmi, M. U. D., \& Nazir, T. (2010). Analyzing financial performance of commercial banks in India: Application of CAMEL model. Pakistan Journal of Commerce and Social Sciences (PJCSS), 4(1), 40-55.

Ünvan, Y. A., \& Yakubu, I. N. (2020). Do bank-specific factors drive bank deposits in Ghana?. Journal of Computational and Applied Mathematics, 112827.

Vodová, P. (2013). Determinants of commercial bank liquidity in Hungary. Finansowy Kwartalnik Internetowy E-Finanse, 9(4), 64-71.

\section{Copyrights}

Copyright for this article is retained by the author(s), with first publication rights granted to the journal.

This is an open-access article distributed under the terms and conditions of the Creative Commons Attribution license (http://creativecommons.org/licenses/by/4.0/). 